Original paper UDC 1:615.851(045)

doi: $10.21464 / \mathrm{sp} 32213$

Received: July 12, 2016

\author{
Marko Tokić \\ University of Zagreb, Faculty of Humanities and Social Sciences, HR-10000 Zagreb \\ tokicmarko@yahoo.co.uk
}

\title{
An Encounter between Philosophy and Modern Psychotherapy
}

\begin{abstract}
The article attempts to uncover a forgotten perspective on healing the human soul-one that does not fall under the history of medicine but rather the history of philosophy, thus emphasising the connection between philosophy and modern psychotherapy. This necessitates an examination of the relationship between modern psychotherapy and modern psychology/psychiatry. It follows that psychotherapy is not significantly defined by knowledge particular to either psychology or psychiatry, even though psychotherapy does encompass procedures grounded in the scientific and theoretical bases of psychology. In conclusion, it is proven that it is not knowledge in the modern sense that acts as a determinant for psychotherapy, but rather a kind of compassion that is characteristic of the philosopher.
\end{abstract}

\section{Keywords}

philosophy, psychotherapy, psychology, psychiatry, neurosis, suffering, compassion

for Irena Bezić and Jadran Morović

Psychotherapy today is most often perceived as the art of ameliorating mental disturbances, and it is considered to fall within the bounds of clinical psychology and psychiatry.* Psychotherapy, in this sense, is considered a modern scientific discipline. However, many of the psychotherapeutic approaches abnegate science.. Modern psychotherapy is scientifically questionable insofar as the psychotherapist uses subjective interpretations and speculative conclusions supported by knowledge of myths or other spiritual formations to prove assumptions about the life of man, as opposed to the use of verifiable data and objective confirmations of evidence exclusively. ${ }^{1}$

In interaction with the patient, the psychotherapist makes use of two different comprehensions of reality. One of these comprehensions derives from the human need for an empirical way of observing reality, while the other derives

$*$

This text is the result of work on the "Philosophical and educational aspects of compassion" project, which was carried out at the Faculty of Humanities and Social Sciences with the support of the University of Zagreb (2016) within the framework of the scientific work of the Centre of Excellence for Integrative Bioethics.
1

Scott O. Lilienfeld, Steven Jay Lynn, Jeffrey M. Lohr (ed.), Science and Pseudoscience in Clinical Psychology, Guilford Press, New York, London 2003. 
from the human need for a symbolic way of observing reality. ${ }^{2}$ The naturalistic view of mental illness developed on the basis of this first need, falling within the jurisdiction of medicine. On the basis of the second need, the spiritual view of mental illness developed, falling within the jurisdiction of philosophy. Thus, mental illness can today be approached either clinically, implying knowledge of illness according to the statistically affirmed division of mental illness of the World Health Organisation and World Psychiatric Association, ${ }^{3}$ or it can be approached philosophically, implying an ontologically-founded knowledge of the nature of human suffering. The clinical approach starts from the belief that man can be absolved of mental illness through external means, similar to how malignant tissue is removed from the body. The philosophical approach, however, starts from the belief that man can absolve himself of his mental illness in an entirely different way than he would of physical illnesses. According to the philosophical conception, every man can find the spiritual strength to heal himself within himself, and can succeed in using his own strength to cure himself of mental illness.

Modern psychotherapy cannot uncompromisingly accept the rule of objective, hypothetical, and experimental assumptions on the nature of human life - it also accepts ontological assumptions on the nature of man. ${ }^{4}$ Despite its belonging to modern science, modern psychotherapy maintains an internal relationship with philosophy.

The connection between philosophy and modern psychotherapy has been recognised both by those devoted to philosophy and those devoted to psychotherapy, however, it remains questionable in large part. In any case, it should be emphasized that this connection is not realized only because of the ever more frequent need to complement the viewpoints of modern psychotherapy with knowledge from the field of philosophy. ${ }^{5}$

To understand the connections between modern psychotherapy and philosophy more clearly, we must first clarify both the relationship between modern psychotherapy and modern science and the psychotherapeutic aspect of philosophy. Such a clarification leads to the discovery of a forgotten perspective on healing the human soul - one that falls under the history of philosophy instead of the history of medicine.

\section{I.}

While the name 'psychotherapy' was used nearly synonymously with psychoanalysis in the early 20th century, many of the psychotherapeutic trends that developed after the 1950s distanced themselves from psychoanalysis. It can be said that scientific psychotherapy developed into three basic divisions: (1) psychoanalytical therapy, (2) humanistic therapy, and (3) cognitive and behavioural therapy. ${ }^{6}$ As Freud significantly connected psychoanalysis with neuroses, and all branches of psychotherapy grew out of psychoanalysis, modern psychotherapy was initially established as the art of ameliorating neurotic symptoms. ${ }^{7}$

William Cullen first used the name 'neurosis' to describe mental disturbances resulting from neurological illness in the $18^{\text {th }}$ century, and his biologistic interpretation prevailed until Freud. ${ }^{8}$ Freud began to accept non-material explanations of the causes of neurotic symptoms, having determined that mental states caused by fantasies arising from unfulfilled desires had a greater impact on neuroses than physical disturbances. ${ }^{9}$ It thus followed that neuroses appear 
as an interpretation of mental life that cannot be explained on the sole basis of bodily biological functions. Freud thus gave rise to a conception of neuroses under which they were no longer considered an illness in the classical sense, but rather a way of life. Thus, after Freud, neuroses were considered first and foremost a particular way of reacting to the conditions of living. ${ }^{10}$

Richard Chessick refers to this symbolic view of reality as "humanistic imagination". Cf. Richard D. Chessick, Why Psychotherapists Fail, Science House, New York 1971, pp. 175-188.

The World Health Organisation publishes the International Statistical Classification of Diseases and Related Health Problems (ICD). The World Psychiatric Association cooperates with the World Health Organisation in editing the chapter on mental and behavioural disorders. The American Psychiatric Association publishes the Diagnostic and Statistical Manual of Mental Disorders (DSM).

The existentialist/humanist approach necessarily implies the ontological issue of the nature of man. Cf. Rollo May, Psychology and the Human Dilemma, Van Nostrand, Princeton 1967, p. 92.

Today, ever greater efforts are underway within the scientific community to build and strengthen the relationship between philosophy and psychotherapy. Many prestigious universities have founded master programmes in philosophy and mental health, which also includes scientific work focused on areas in which philosophy and psychotherapy overlap. These efforts have also resulted in the following books: R. D. Chessick, Why Psychotherapists Fail; Chris Mace (ed.), Heart \& Soul: The therapeutic face of philosophy, Routledge, London 1999; Donald Robertson, The philosophy of cognitive-behavioural therapy (CBT): Stoic philosophy as rational and cognitive psychotherapy, Karnac, London 2010

According to the Research Task Force of the National Institute of Mental Health (1975), more than 250 new branches of psychotherapy exist today. Cf. Barry L. Duncan, Mark A. Hubble, Scott D. Miller, Escape from $\mathrm{Ba}$ bel. Toward a Unifying Language for Psychotherapy Practice, Norton, New York 1997 pp. 1-2.

In order to be able to claim that psychoanalysis is nothing more than the psychology of neuroses, see: Otto Fenichel, The Psychoanalytic Theory of Neurosis, Norton, New York 1945.
8

José M. López Piñero, Historical Origins of the Concept of Neurosis, Cambridge University Press, Cambridge 1983, pp. 11-16.

9

According to Freud, neuroses are caused by the delusional ideas (Wahnideen) that make up the unconscious mind - people differentiate among themselves because of the different content of these and similar ideas. $\mathrm{Cf}$. Sigmund Freud, Gesammelte Werke - Band XI. Vorlesungen zur Einfuhrung in die Psychoanalyse, S. Fischer, Frankfurt am Main 1969, p. 257. Freud believes that neuroses can be uncovered by learning about resistance and suppression, the unconscious, the etiological meaning of sexual life, and the significance of childhood experiences. Cf. Sigmund Freud, Gesammelte Werke - Band XIV. Selbstdarstellung, Imago Publishing Co., London 1955 , p. 65

10

Harry Stokholm, "Our Concept of Neurosis: A Brief Critical Comment", Acta Psychiatrica Scandinavica 31 (S108/1957), pp. 363-366. doi: https://doi.org/10.1111/j.16000447.1956.tb01699.x. If neurosis is defined in strict medical terms, it is viewed as a mental illness featuring either (1) symptoms characteristic of a clinically significant (conversive) disorder, or (2) symptoms typical of an anxious disorder that excludes psychosis. However, if neurosis is viewed in philosophical terms as a spiritual way of life, then - regardless of the patient's clinical picture - it is viewed in the light of a psychopathology characteristic of human life. Cf. Ernesto Spinelli, Practising existential psychotherapy: the relational world, Sage Publications, Los Angeles - London - New Delhi - Singapore 2007 p. 27. Anxiety is a determinant of neurosis. As opposed to the medical viewpoint, according to which neurosis is equated with particular symptoms that should be treated, the philosophical viewpoint considers neurosis a vital, natural part of the human existence. In this sense, modern theoreticians differentiate between neurotic anxiety (a determinant of the clinical conception of neuroses) from existential anxiety (a determinant of the ontological conception of neuroses). However, these two kinds of anxiety are not necessarily mutually exclusive - in his attempts to avoid existential anxiety, man attains certain behavioural and thought patterns that, in the end, can be equated with symptoms of neurotic anxiety. Thus, it is not incorrect to think that many differ- 
The multitude of neurotic symptoms, from various phobias to different kinds of compulsive behaviour, reflect a struggle with oneself resulting from unsolved internal conflict. ${ }^{11}$ Regardless of the doctrine a particular branch of psychotherapy relies on, every psychotherapist discovers in their patients a low level of self-awareness, a certain confusion, lethargic indifference, and feelings of anxiety that lead patients to believe they are constantly missing out on something in life. These are feelings that correspond to alienation. In ancient philosophy, especially in the Platonic tradition, these feelings are described as a wandering of the soul, and cause people to think they are outside of their own selves. If we take into account that Freud expressly connects his doctrine of neurosis with Plato, it might not be so wrong to attempt to portray this mental state in light of Plato's conception of illness of the soul, ${ }^{12}$ especially because Plato describes such illness in The Sophist (227d-229a) in a manner similar to modern interpretations of neurosis:

"Well then; do we not see that in the souls of worthless men opinions are opposed to desires, anger to pleasures, reason to pain, and all such things to one another?" (Sophist 228b)

According to Plato, all various and opposing forces in life - the desire for physical comforts, anger, fear, hope, supposition, belief, the ability to perceive or reason - can be reduced to two opposing halves of the soul. One is that half which man uses to attain bodily pleasures, and the other is the half which man uses to attain mental pleasures. Plato considers man to be able to live in essentially two different ways: (1) in accordance with himself, creating harmony between the opposing halves of his soul, or (2) in disharmony with himself, creating hostility between the opposing halves of his soul. Man is mentally ill insofar as he is in disharmony with himself, either disregarding mental pleasures in favour of the body and bodily pleasures or disregarding the body and bodily pleasures in favour of mental pleasures. ${ }^{13}$

Plato offers a string of exercises to correct the exaggerated influence of the body on the soul and the soul on the body, aimed at establishing a harmonious relationship between body and soul. In doing so, he focuses less on discovering traumatic childhood experiences and more on uncovering the cause of disbalance in the soul, which prevents the establishment of a healthy life. However, with all the differences in research into mental illness between Plato and representatives of modern psychotherapy, the foundational experience of internal disharmony witnessed by Plato is the very one also witnessed by modern psychotherapists two thousand years later. The strength of the many parallels between Plato's discourse on illness of the soul and modern doctrine concerning neurosis can be witnessed by what Alexander Lowen writes of neuroses:

"A feeling is a biological reaction of the body which is beyond the dictates of the ego. The ego's role is to perceive feeling, not to judge or to control it. What is within its control is action. A healthy person who feels angry or sexually excited is able to contain his feelings until an appropriate occasion arises for their expression. This produces responsible behaviour. A healthy ego is not helpless in its relation to the body. If the expression of a feeling in word or deed would be harmful, the ego can restrain this expression through its control of the voluntary musculature without at the same time denying or repressing the feeling. Harm is thereby avoided without creating an inner conflict."14

According to Lowen's conception - one shared by many other psychotherapists - internal conflict is not a pathological disorder that a handful of individuals suffer from, but rather an emotional disorder from which all individuals suffer to a certain extent. ${ }^{15}$ Plato equates this disorder with madness, which is reflected in two ways - frenzy and dullness. ${ }^{16}$ Both forms of madness are ill- 
nesses of the soul, as opposed to physical illnesses, although they are caused by bodily processes. Whenever man is able to realise a particular pleasure, whether bodily or mental, he then becomes so physically excited as to lose sight of the unity of body and soul. With his reason muddled, he equates himself entirely with his body, unwittingly taking advantage of the body's natural functions to engage in overindulgence and thus disturbing his mental health. This creates feelings of resentment, despondency, impertinence, fearfulness, or even forgetfulness, which further results in the dullness common to dissociation (Timaeus $87 \mathrm{a}-\mathrm{b}$ ).

Plato's interpretation of mental illness is ontological in nature, and according to this interpretation, mental illness is any manner of suffering caused by a lack of awareness of the unitary nature of the soul. ${ }^{17}$ Individuals with low

ent, specific disorders that can fall within the clinical picture of neuroses are only different forms of an unauthentic confrontation with existential anxiety. Along these lines, Tillich ontologically defines neurosis as "the way of avoiding nonbeing by avoiding being". See: Paul Tillich, The Courage to Be, Yale University, New Haven 2000, p. 66. It thus seems that the patient, if he desires to realise an authentic way of life, must learn to listen to what his neurotic anxiety is trying to tell him. By doing so, he actually learns to authentically accept his existential anxiety. Thus, the term "neurosis" in this paper shall refer to a potentially positive phenomenon, and shall attempt to interpret it philosophically (platonically).

11

Freud explains this type of conflict as an opposition between ability to judge (ego) and inappropriate desires (id). This kind of conflict is explained in existentialist therapy as an opposition between the need for self-knowledge and self-forgetfulness, while Gestalt psychotherapy explains it as an opposing division between vital actions the nature of which is to tend towards harmonious unification (socalled polarities). Cognitive behavioural psychotherapy defines it as a conflict regarding alternative courses of action. For more on cognitive behavioural therapy see: Aaron T. Beck, Cognitive Therapy and the Emotional Disorders, Meridian, Boston 1979.

\section{2}

In his autobiography (1924), Freud writes: "I was aware that in deriving hysteria from sexuality I was going back to the very beginnings of medicine and following up a though of Plato's." See: S. Freud, Gesammelte Werke - Band XIV, p. 49. On Freud's inheritance of Plato's conception of the soul, see: Fabio Stok, "Sigmund Freud's Experience with the Classics", CLASSICA 24 (1-2/2011), pp. 68-70. doi: https://doi.org/10.14195/2176643624 4; Stella Sandoford, Plato and Sex, Polity Press, Cambridge 2010, pp. 71-98.

13

According to Plato, the dynamics of disregarding one of the two opposing halves of the soul is a determinant for the establishment of conflict between body and soul. According to Plato, there can be no healthy life if the soul disregards any aspect of life. Man must live for the benefit of both body and soul, as both those who suppress the body and bodily pleasures in favour of mental pleasures and those who suppress mental pleasures in favour of bodily pleasures live as if they are lame (Plato, Resp. 535d-e). 14

Alexander Lowen, The Betrayal of the Body, Collier Books, New York 1976, p. 262.

15

One of the most important results along these lines is the remarkable work of Karen Honey. Cf. Karen Horney, The Neurotic Personality of Our Time, W.W. Norton \& Company, New York 1937; Karen Horney, Our Inner Conflicts - A Constructive Theory of Neurosis, W.W. Norton \& Company, New York 1945.

16

"Such is the manner in which diseases of the body come about; and those of the soul which are due to the condition of the body arise in the following way. We must agree that madness is a disease of the soul and of disease there are two kinds, the one which is frenzy, the other dullness. Whatever affection a man suffers from, if it involves either of these conditions it must be termed disease; and we must maintain that pleasure and pains in excess are the greatest of the soul's diseases." See: Plato, Timaeus 86b-c. Along these lines, see: Kenneth Seeskin, "Plato and the origin of mental health", International Journal of Law and Psychiatry 31 (6/2008), pp. 487-494. doi: https://doi.org/10.1016/j.ijlp.2008.09.004

17

Galen provides what is perhaps the most precise ontological determinant of illness (De placitis Hippocratis at Platonis, V, 2.39-43):

"Disease is a higher and more general term than was indicated by the statement I made a moment ago. Let us therefore give a comprehensive definition of the concept: it is "the 
levels of awareness of the unity of their various vital abilities overindulge in pleasures to such an extent that they are unable to reasonably judge what is good for them and what is not. Every individual participates in this manner of suffering in his or her own way. ${ }^{18}$ From birth, individuals suffer various unjust injuries from the many other individuals surrounding them. They are thus overwhelmed by passion. As it is difficult for individuals to control themselves in such cases, they often unconsciously harm others themselves. This creates a vicious circle of suffering. A sensible view of this makes it apparent that no one harms anyone else intentionally. Plato does not believe that the cure for this type of suffering is to control oneself to such an extent that we divest ourselves of our passion. According to Plato, man must have passion. However, passion is healthy only if it is paired with kindness - all individuals should always have the power to express their anger towards those who have injured them on one hand, but they should also be ready to forgive, because the truth of the matter is that no one actually harms anyone intentionally. Passion is the power to defend one's mental health if it is paired with kindness (Laws 731b-e).

As we all take equal part in the creation of suffering, from which is it extremely difficult to escape, perhaps it is best to accept suffering as a component part of human existence. According to Plato, man does not suffer only because others carelessly harm him - he also suffers from the trauma of birth and dying, as well as from the impossibility of having a perfect body; to a great extent, man also suffers due to his having adopted many inappropriate opinions resulting from the careless actions of his parents (Timaeus $87 \mathrm{~b}-\mathrm{c}$ ). ${ }^{19}$

Because man is unable to divest himself of suffering, he is inevitably overwhelmed by existential angst, and as a result, life occasionally becomes an unbearable burden. ${ }^{20} \mathrm{He}$ thus exerts great efforts to rid himself of suffering, doing so by always choosing only those things that are pleasing to him. The result of this is the conceit that it is good to create a life that is completely devoid of suffering. This and similar conceits are the cause of madness - they inspire man to enjoy pleasures to excess because he is burdened with disturbing emotions to such an extent that he can see nothing more than the suffering he wishes to rid himself of completely.

Plato notes that it is unreasonable to strive for a life completely devoid of pain and suffering, because it is in the nature of all humans to err and harm others. It is just as unreasonable to strive for a life completely devoid of suffering as it is to strive for a life completely devoid of pleasure. Only that which is natural is reasonable, and that is a life in which pain and pleasure enjoy a balance measured by a particular feeling of good that man may attain if, not adhering to disturbing emotions, he chooses those things to which he is inclined and which make him happy (Laws 733b-e). In the end, this means that a mentally healthy life does not only imply the establishment of a balance between mental and bodily pleasures with the aid of appropriate discernment, but also the establishment of a healthy balance between pleasure and pain of both kinds with the aid of the expression of passions and kindness.

It can be said that Plato's philosophy claims that this art of living enables insight into the nature of suffering. What determines this philosophy is the belief that man, with enough effort, can heal himself - in the case of mental illness, he does not need external aid in the same sense as when he seeks medical aid when physically ill. It was in the light of this conception of philosophy that Cicero began to describe philosophy as medicina animi: 
"A medicine for the soul (medicina animi) actually exists: philosophy, whose help we do not have to seek outside ourselves, as we do when the body is ill; rather we must struggle with all our might and main to be to ourselves our own doctors." 21

Philosophy perceived as medicina animi is not directed at those expressions of mental illness that can be reasonably connected with excessive secretion of black bile or with illnesses of the brain - rather, it does not examine the medical states of melancholy or epilepsy, but is instead focused on the upsetting emotional states of anger, joy, sadness or lethargy. ${ }^{22}$ Cicero thus expressly notes that philosophers consider mental illness to be the suffering borne by man as a result of emotional distress, not those disorders that can be ameliorated through knowledge of the Hippocratic art of medicine (Tusculanes III, 7). It thus follows that, since ancient times, a philosophical perception of mental illness has developed parallel to the purely medical perception of mental illness. This interpretation does not view philosophy as the establishment of learning abstract theory, but as a psychopathology that is ontologically founded as psychotherapy, or the art of mental practices designed to free individuals of their suffering. ${ }^{23}$

In conclusion, the following division of doctrines on mental illness is possible: ${ }^{24}$

destruction of what is by nature congenial as the result of some dissension'. That was Plato's definition in the Sophist. It is not difficult to ascertain that this formulation is at a higher level and accurately covers all particular diseases, those of our soul, those of our body, those found in other animals and plants, and even those of whole cities. Thus we say, I believe, that cities divided by civil war are internally diseased, as though their components, congenial by nature, had come to blows. This is the most generic concept of all disease The mutual conflict of the simplest parts is less generic than this, and still less generic is the statement that disease is a lack of proportion of things hot, cold, dry and wet. For this (last) is disease of the body only, and of nothing else, just as the conflict of the rational is disease of nothing but the soul". According to the original text in: Galen, On the Doctrines of Hippocrates and Plato, Akademie-Verlag, Berlin 1978

18

It is along the lines of this very conception of mental illness that the stoics proclaimed all people are fools - every man, holding to disturbing emotions, is in a way mentally ill; only the enlightened wise man is absolved of mental illness. Cf. Margaret Graver, Stoicism and Emotion, University of Chicago Press, Chicago - London 2007, p. 111. doi: https://doi.org/10.7208/chicago/9780226305202.001.0001.

19

Plato especially blames parents who tend to drink alcohol to excess, holding that such parents are most likely to embitter their children's lives (Laws 775b-776a)
20

See footnote 10 .

21

Cicero, Tusc. III, 6: "Est profecto animi medicina, philosophia; cuius auxilium non ut in corporis morbis petendum est foris, omnibusque opibus viribus, ut nosmet ipsi nobis mederi possimus, elaborandum est. Quamquam de universa philosophia, quanto opere et expetenda esset et colenda, satis, ut arbitror, dictum est in Hortensio." According to the original text: Max Pohlenz (ed.), M. Tullius Cicero: Tusculanae disputationes, Teubner, Leipzig 1918. [= Tusculanes].

22

Tardarum passionum libri, I. 150, in: Caelius Aurelianus, Akute Krankheiten Buch I-III. Chronische Krankheiten Buch I-V. Teil I [= Corpus Medicorum Latinorum, VI, 1], Akademie Verlag, Berlin 1990.

23

In this sense, ancient philosophy is most interpreted by Pierre Hadot and Marta Nussbaum. Cf. Pierre Hadot, Philosophy as a Way of Life - Spiritual Exercises from Socrates to Foucault, Blackwell, Oxford 1995; Marta C. Nussbaum, The Therapy of the Desire. Theory and Practice in Hellenistic Ethics, Princeton University Press, Princeton 2009.

24

Debra Hershkowitz, The Madness of Epic. Reading Insanity from Homer to Statius, Clarendon Press, Oxford 1998, pp. 1-14. 
(1) According to medical (empirical) doctrine on mental illness, all forms of madness, both curable and incurable, are caused by a specific imbalance in the body. Both in ancient and modern empiricists claim that there is no form of madness whose cause cannot be reduced to the body and described as a physiological phenomenon. Empiricists thus view the 'mental' part of mental illness only metaphorically. Mental illnesses fall under physical illnesses, and thus lie under the jurisdiction of medicine. $^{25}$

(2) According to the philosophical (ontological) doctrine on mental illness, all forms of madness are caused by bodily imbalance, however their appearance is also significantly influenced by stresses independent of the body. Both ancient and modern psychologists who accept the ontological explanation of illness consider mental illnesses, which come about through the mediation of the body, to be 'mental', and not physical. Although mental illness can be reduced to a physical cause in a way, its essence cannot be explained empirically. As opposed to the incurable type, the curable type of madness can be treated - in addition to medical treatment - by uncovering the nature of suffering (existential angst), which is in the jurisdiction of philosophy.

It is apparent that ancient philosophers and representatives of modern psychotherapy in a way share the same perception of mental illness. Aware that specific mental disorders occur in all people to a certain extent, representatives of modern psychotherapy do not perceive their patients as suffering from an illness in the true sense of the word, but rather as individuals whose suffering expresses the inescapability of human nature. As psychotherapists today are aware of the fact that neuroses become bearable only when the patient becomes aware of their suffering as a component part of their mental existence, they approach their patients like the ancient philosophers, despite having inherited the methodology of modern science:

"Not that the tie between mind and instinct is necessarily a harmonious one. On the contrary it is full of conflict and means suffering. Therefore, the principal aim of psychotherapy is not to transport the patient to an impossible state of happiness, but to help him acquire steadfastness and philosophic patience in face of suffering. Life demands for its completion and fulfilment a balance between joy and sorrow." 26

\section{II.}

What distances modern psychotherapy from clinical psychology and psychiatry is the belief that neurotic symptoms have a deeper (ontological) sense. First and foremost, this means that psychotherapists believe that their patients can be cured of mental disorders by discovering the power of healing within themselves, not with the external means used to treat bodily illnesses. Psychotherapy can thus help individuals to become aware of themselves by recognising and accepting their neurotic symptoms in the broader context of their lives. The psychotherapist is prepared to believe that the establishment of mental health depends on the individual, specific ways in which neurotic symptoms come about and disappear, as well as on the completely different manners in which neurotic ideas can be overcome. Every person should become aware of the specificities of their own psychic system, which develops from childhood. It is necessary for individuals to make themselves aware of 
all of their injuries, even those suppressed in childhood, in order to realise their healing passions.

The psychotherapist, in encountering an individual displaying neurotic symptoms, is prepared to accept human weakness, and if necessary, to disregard the authority of modern science. This is because, in conversation with a patient, he or she cares more about the truth of the patient's life than about accepted perspectives on mental illness, even when he or she is not consciously aware of it. In such a conversation, the psychotherapist is not focused on establishing a diagnosis, but on discovering and accepting the suffering that defines the patient's way of life:

"Psychotherapy deals with the sufferer. Who is the sufferer? Is he only the bearer of a certain diagnosable disease? ... In scientific psychotherapy Freud was the first to see the personality as a whole. He thought that to understand the symptoms one must understand the life of the personality who suffers from symptoms. He was a wonderful beginning." 27

Thus, as opposed to psychotherapy, which is directed at the subjective experiences of a particular individual, clinical psychology and psychiatry are aimed more at researching that which is independent of a particular individual. In his first lecture from A General Introduction to Psychoanalysis, Freud mentions that the psychiatrist - by establishing a diagnosis based on a medical history and observation - judges the patient systematically, like a museum piece, while the psychotherapist experiences the patient through his or her words. Words uncover the specificities within the life of an individual, which softens mental suffering more acutely than any hard-scientific psychiatric means:

"Words were originally magic, and the word retains much of its old magical power even to-day. ...Words call forth affects and are the universal means of influencing human beings. Therefore let us not underestimate the use of words in psychotherapy, and let us be satisfied if we may be auditors of the words which are exchanged between the analyst and his patient." 28

25

Mirko Dražen Grmek, one of the most influential medical historians in the world, claims that clinical psychologists and psychiatrists today completely accept only the possibility of empirical descriptions of diseases, and stubbornly negate the problem of the internal conflict that man suffers because of the duality of body and soul: "In modern medical diagnostics there is an effort to conceal, to ignore deliberately, the problem ensuing from the mind-body duality. This duality is conceptualized and it affects our thinking in such a way that the problem which it raises cannot be solved, or suppressed, without some kind of metaphysical considerations trespassing the frontiers of medical knowledge." See: Mirko Dražen Grmek, "Historical Reflections on Psychiatric Clinical Entities", in: Joseph Agassi (ed.), Psychiatric Diagnosis, Balban International Science Services, Philadelphia 1981, p. 89

26

Carl G. Jung, "Psychotherapy and a Philosophy of Life", in: Carl G. Jung, The Practice of Psychotherapy. Essays on the Psychology of the Transference and other Subjects, Bollingen Series XX, New York 1954, p. 81.
27

Wladimir Eliasberg, "Philosophy of Psychotherapy", in: Philosophy of Science 13(3/1946), p. 203. doi: https://doi.org/10.1086/286896. 28

S. Freud, Gesammelte Werke - Band XI, pp. 9-10. It is apparent that, at some point in his medical career, Freud began to rely exclusively on conversation. Prior to this, he treated patients through hypnosis. Hypnosis places patients in a trance-like, unconscious state in which they are able to gain access to traumatic experiences and abreact them in a hysterical attack. Historically, this kind of psychiatric treatment procedure is tied to Franz Anton Mesmer (1734-1815). In Freud's An Autobiographical Study, he claims that the results of this type of treatment were key to the creation of psychoanalysis. Cf. S. Freud, Gesammelte Werke - Band XIV, pp. 43-54; Henri F. Ellenberger, The Discovery of the Unconscious. The History and Evolution of Dynamic Psychiatry, Fontana Press, London 1944, pp. 57-102. 
While psychiatry observes mental processes primarily in relation to the natural sciences, oriented towards the body and nervous processes, ${ }^{29}$ psychotherapy, believing in the expression of the mental experience through words, inquires more into the invisible relationships between internal phenomena than into perceptible physiological phenomena. Modern psychotherapy cannot be strictly empirically founded, because it always strives to display the unseen and imperceptible. It was along these lines that Freud pointed out in his $A$ General Introduction to Psychoanalysis that the therapeutic aspect of psychoanalysis is composed of a quite specific approach to the patient, one that is unknown to biologistically-oriented psychiatrists. For this reason, despite attempting to remain devoted to the empirical sciences throughout his entire career, Freud diverged somewhat from the model of scientific empiricism. Not only did some of Freud's contemporaries consider his psychoanalysis to diverge from the unilaterally objective principles of empirical science, ${ }^{30}$ some recent interpreters do as well:

"This was not philosophy, in an orthodox sense; it was an expression of his humanism. (...) Freud struggled with fitting the scientific mode of knowing within the broader therapeutic agenda he set himself. For him, science did not function solely as some kind of separate intellectual or technical activity to study the natural world, but rather became an instrument to help define human realities in the humane quest of knowing the world in order to place ourselves within it. So, despite Freud's commitment to empiricism and the scientific objectivity he claimed for his method, he began and ended his career with responses to perplexing questions about the nature of man, the history of culture, and the place of religion in the face of humanity's search for meaning." 31

The psychiatry out of which Freud developed his psychoanalysis inherited natural science, which began forming in the early modern era. Aside from psychiatry, psychology also inherited natural science. In the late 19th century, it nearly entirely split off from philosophy, tending towards a conception of mentality that would correspond with the causal laws of the external, physical world. Thus, psychology severed itself from the rich heritage of philosophical observations of life. However, the strongest opposition to this attempt of the new psychology to comprehend psychic processes exclusively through the category of the natural sciences came from Wilhelm Dilthey. According to him, the mental life of man consists of a series of experiences that, as they are both socially and historically determined, are not empirical facts. Thus, he insists on the foundation of a difference between the natural sciences (Naturwissenschaften) and the 'sciences of spirit' (Geisteswissenschaft). ${ }^{32}$ While nature explains, spiritual life and the spirit understand. As a science determined by understanding, psychology is a science of spirit, not a natural science. ${ }^{33}$ And as the term 'science of spirit' entered use at the time synonymously with philosophical science, a psychology that opposes the natural sciences is implicitly a philosophical science.

Husserl continued along the line of Dilthey and created the psychological process of eidetic reduction, which consists of the exclusion or bracketing (Einklammerung) of a natural characteristic, resulting in the establishment of transcendental awareness through which man can directly discover essence (Wesensschauung). ${ }^{34}$ It was not only Husserl's phenomenological psychology that developed under the influence of Dilthey's psychology - other forms of philosophical psychology also developed, like Spranger's humanistic philosophy, Jaspers' psychopathology, and Gadamer's hermeneutic psychology.

Freud, being on the side of empiricism, takes a critical approach towards philosophy. However, he does not take a critical approach towards the conception of philosophy as medicina animi, but rather a new philosophy - one 
embattled with the empirical sciences and aimed at the creation of a priori scientific procedures. The task of healing the mind would surely no longer fall under the jurisdiction of this type of philosophy, as it would have elevated itself above the experience of everyday suffering. Freud's humanism, thus, should be perceived in the light of the old philosophy (medicina animi), not the new type of philosophy ('science of spirit'). ${ }^{35}$

Built on the foundations of modern natural philosophy as a positivist and experimental science, a psychology oriented towards the natural sciences inherits an empirically-founded theory of knowledge. Built on the foundations of German idealism as a philosophical science, a psychology oriented towards the 'science of spirit' inherits a hermeneutical and phenomenological theory

29

In the early 19th century, J. C. Reil gave the name 'psychiatry' (Psychiaterie) to the neurological study of mental illness. In the 18th century, doctors frequently studied mental illness under the auspices of neurology, considering that mental illness had a bodily cause. A mentally ill individual was considered, in the Cartesian spirit of the neurologists of the time, as a sensory-motor machine in disrepair. They harmonised their neurological interpretations with Locke's and Hume's teachings on perception. However, opposite them were those doctors who, under the influence of these same empirical teachings, refused to reduce the causes of mental illness to the body, such as Thomas Arnold (1795-1842). This non-material approach to mental illness during the Enlightenment shaped the medical theory on the basis of which moral therapy was established. The most instrumental figure in moral therapy was French doctor Philippe Pinel (1745-1826). Materialistic and non-materialistic approaches to mental illness developed in parallel. In Germany, J. C. A. Heinroth and K. Ideler were the key representatives of the non-material approach to mental illness, while the main representative of the materialistic approach in Germany was Wilhelm Griesinger, who, according to Karl Jaspers, was the true founder of modern psychiatry. We can thus consider modern psychiatry the successor to the materialistically-oriented medical approach to menta illness, which was developed at universities and in clinical brain anatomy laboratories. In General Psychopathology, his greatest work, Jaspers claims multiple times that modern psychiatry cannot be understood without an acceptance of Griesinger's claim that mental illnesses are illnesses of the brain. Therefore, regardless of the fact that psychiatrists today undergo psychoanalytical training, and that psychiatry occasionally accommodates to existential philosophy, modern psychiatry's determinant is the physiology of the nervous system. Cf. Karl Jaspers, Allgemeine Psychopathologie, Springer, Berlin 1946, p. 706; Roy Porter, Madness: A Brief History, Oxford University Press, Oxford 2003, pp. 123-156; Edwin R. Wallace, John Gach (ed.), History of Psychiatry and Medical Psychology. With an Epilogue on Psychiatry and the MindBody Relation, Springer, New York 2008.

30

Eduard Spranger claims that Freud follows the principle of psychologica psychologice, using a process similar to the Socratic method to reach an understandable (humanistic) psychology. Cf. Edmund Spranger, Psychologie des Jugendalters, Quelle und Meyer, Leipzig 1925 , p. 130. Freud's humanism is perhaps best expressed in his work entitled Eine Schwierigkeit der Psychoanalyse. See also R. D. Chessick, Why Psychotherapists Fail, p. 184.

3

Alfred I. Tauber, "Freud's Philosophical Path. From a Science of Mind to a Philosophy of Human Being", in: Scandinavian Psychoanalytic Review 32 (1/2009), pp. 32-43, p. 41. doi: https://doi.org/10.1080/01062301.2009. 10592639 .

32

There is no sufficient English translation of the German word Geisteswissenschaft. Most often, the lacking "human science" is used, as are often "mental science" or "systematic scholarship".

33

Wilhelm Dilthey, "Ideen über eine beschreibende und zergliedernde Psychologie", in: W. Dilthey, Gesammelte Schriften, Band V, Teubner, Leipzig - Berlin 1924, pp. 139240 .

34

Edmund Husserl, Gesammelte Werke (Husserliana), Band III/1: Ideen zu einer reinen Phänomenologie und phänomenologischen Philosophie. Erstes Buch: Allgemeine Einführungin die reine Phänomenologie. Neu herausgegeben von Karl Schuhmann. 1. Halbband. Text der 1-3, Auflage, Martinus Nijhoff, Den Haag 1976.

35

F. Stok, "Sigmund Freud's Experience with the Classics", pp. 68-70. 
of knowledge. While representatives of natural scientific psychology attempt to excoriate essentialism from psychology, representatives of the science of spirit psychology nurture essentialism in psychology. The opposing sides of psychological theory do not separate by excluding each other - instead, they often approach each other, resulting in various forms of modern psychology that represent a complex interweaving of philosophical and positivistic trends. ${ }^{36}$

As modern psychotherapy examines the life of man as something conditioned by both nature and spirit, it leans on both the natural sciences and the philosophical sciences (humanities).

"...the real point is the treatment of the whole psychic human being. ... and this comes precisely from the fact that the human psyche has a share in all the sciences, because it forms at least half the ground necessary for the existence of them all. ... Yet whereas medicine in general can limit its borrowings to the natural sciences, psychotherapy needs the help of the humane sciences as well." 37

However, modern psychotherapy is also not scientific in the way that philosophical or humanistic psychology is a science, nor in the way that natural science psychology or experimental (positivist) psychology is a science, nor is it scientific in the sense of any other form of modern psychology. Psychotherapy cannot be a science in the sense that psychology is a science.

The fact is that representatives of psychoanalytical and cognitive-behavioural psychotherapy mainly use procedures founded on the discoveries of experimental psychology and neurology (psychiatry), while representatives of humanistic psychotherapy mainly use procedures founded on the discoveries of phenomenological, hermeneutic, or existential psychology. ${ }^{38}$ However, on this basis, we can conclude only that some psychotherapists prefer a natural science world view while others prefer a science of spirit world view. It is therefore impossible to conclude that psychotherapists undertake the task of science.

In fact, psychotherapists are often also psychologists, and occasionally the type of psychologist that aims to make new discoveries in their science. Freud is perhaps the best example of a psychotherapist who, in addition to carrying out therapeutic mental care, simultaneously developed his own original scientific theory. Eduard Spranger writes the following regarding this:

"Freud's psychoanalysis, in fact, initially developed as a method of treatment (Behandlungsmethode), as psychotherapy, and it thus bears a certain one-sidedness that might have been avoided if the entirety of the theory had been established as the initial requirement, and the therapeutic application as the secondary requirement." 39

Psychotherapy can be analysed with a view to the scientific theoretical elements from which it begins, however its task does not significantly depend on such elements. Psychotherapists - at least those who see the therapeutic aspect as the initial requirement of their work - apply scientific principles neither to master scientific knowledge about the mental life of man nor to treat patients using external means, but rather to enable patients the conditions under which they may find within themselves the strength to heal themselves.

The psychotherapist does not discover that what is general or statistically measurable - the determinants of psychology and psychiatry - but that what is singular and unique. An example of these would be an individual's experience of their own dreams. The subject of psychotherapy is too subjective to be scientifically objectivised. When a patient begins to accept him or herself as a system unique in its singularity, the task of psychotherapy has been acchieved. It follows from this that psychotherapy is realised in the lack of scientific knowledge of man as such, that is, in the non-scientific knowledge of 
the idiosyncrasies of each individual. In other words, it is realised in knowledge that is not subject to scientific interest. ${ }^{40}$

\section{III.}

What is common to the many branches of psychotherapy is the belief that patients can, with enough effort and after being subjected to the techniques of the psychotherapist, cure themselves by their own strength. ${ }^{41}$ This belief implies particular factors in the efficacy of psychotherapy. Modern research has shown that, regardless of the psychotherapeutic approach concerned, relationship factors are among the most important for increasing the effectiveness of therapy. Thus, all branches of psychotherapy more or less start from what Carl R. Rogers considers the foundation of psychotherapy. ${ }^{42}$ This is a very particular kind of patience that can be conceived of as compassion. ${ }^{43}$ The determinant characteristics of this kind of compassion are an honesty and understanding that are free of self-interest.

It is thus apparent that the beginnings of psychotherapy do not lie in any manner of scientific theory, but instead in the reflective feeling of a compassionate being. This is a state of consciousness close to the innocent, childish acceptance of everything that appears. It is a kind of passion for wondering at life. It is surely not a passion that might cause a mental illness, which the ancient philosophers attempted to overcome with spiritual exercises, but rather the

36

Wilhelm Windelband, "History and Natural Science", in: Theory and Psychology 8 (1/1998), pp. 5-22. doi: https://doi.org/10.11 $77 / 0959354398081001$.

37

Carl G. Jung, "Medicine and Psychotherapy", in: C. G. Jung, The Practice of Psychotherapy, pp. 89-92.

38

Lewis R. Wolberg, The technique of psy chotherapy, Grune and Stratton, New York 2013.

39

E. Spranger, Psychologie des Jugendalters, p. 129.

40

Perhaps the strongest influence on the terms of knowledge belonging to modern psychotherapy - especially on existential and gestalt psychotherapy - was exerted by a philosophical work by Martin Buber entitled Ich und Du, later translated into English as I and Thou. Cf. Martin Buber, Ich und Du, Reclam, Stuttgart 2009. This is knowledge that arises on the basis of the very particular existential contact of one individual with another. Such knowledge has become a determinant in modern psychotherapy. For a conversation between Martin Buber and Carl Rogers on this subject, see: Judith Buber Agassi (ed.), Martin Buber on Psychology and Psychotherapy. Essays, Letters, and Dialogue, Syracuse University Press, Syracuse - New York 1999, pp. 246-273.
41

Along these lines, Miller, Duncan, and Hubble claim the following: "When the practice of psychotherapy is guided by a unifying language, therapeutic technique stops being a reflection of particular theoretical doctrine or school of therapy and instead becomes the vehicle for enhancing the effects of the other common factors. The immediate result is that therapists spend less time trying to figure out the right intervention or practicing the right brand of therapy and spend more time doing what they do best: understanding, listening building relationships, and encouraging clients to find ways to help themselves (...) Whatever model is employed, however, most therapeutic procedures have the common quality of preparing clients to take some action to help themselves." See: Barry L. Duncan, Mark A. Hubble, Scott D. Miller, Escape from Babel. Toward a Unifying Language for Psychotherapy Practice, pp. 27-29.

42

Cf. Adam O. Horvath, Lester Luborsky, "The role of the alliance in psychotherapy", Journal of Consulting and Clinical Psychology 61 (4/1993), pp. 561-573. doi: https://doi. org/10.1037//0022-006x.61.4.561.

43

Cf. David G. Martin, Counseling and Therapy Skills, Waveland Press, Long Grove 2000. 
kind of passion that - by taking part in the primordial nature of good - enables man to experience a complete life, and inspires him to make an effort to cultivate this kind of experience in order to change his life. ${ }^{44}$

According to Rogers' influential discussion on the essence of modern psychotherapy, On Becoming a Person, the psychotherapist realises the compassion required for psychotherapy if he succeeds in appropriately directing himself towards the patient. If the psychotherapist is appropriately directed towards the patient, he visibly displays that he honestly feels how terrifying the patient's world is. The psychotherapist at this point readily wishes to feel the patient's feelings. The more compassionate the psychotherapist is, the more the patient trusts the psychotherapist with each passing moment. The patient then feels that the psychotherapist understands his feelings and that he can see his suffering through his eyes. At such a moment, the psychotherapist can humanely offer support to the patient and encourage him to express his anger, love, sadness, or any other emotion, desire, or thought hiding within him. The psychotherapist wishes for his feelings to be clear to the patient, and for the patient to differentiate them from his own feelings. At moments when the patient is completely overcome by fear and cannot rid himself of it, thus experiencing the psychotherapist as a kind of threat or someone who cannot understand his suffering, the psychotherapist perhaps most needs to become compassionate, accepting the patient's feelings and doubts, without making any efforts to disprove them, hoping that the day will come again when the patient will be able to clearly perceive him as someone who understands and supports him:

"It involves the courage to be. It means launching oneself fully into the stream of life. Yet the deeply exciting thing about human beings is that when the individual is inwardly free, he chooses as the good life this process of becoming." 45

If it can be claimed that this psychotherapeutic approach to the patient is what significantly defines the art of psychotherapy, then all representatives of modern psychotherapy, whether consciously or unconsciously, approach the Socratic art of discussion and realise a historical encounter with philosophy in a particular way. In the entirety of Plato's early dialogues, where Socrates' therapeutic power of the word is most expressed, it is apparent that Socrates does not aim to teach any philosophical or scientific system - and the same can be said of Plato to a fair degree of certainty - but rather to enter an honest relationship with himself in order to establish a compassionate relationship with other human beings, whom he wishes well. ${ }^{46}$

The compassion characteristic of psychotherapy does not imply the experience of scientific knowledge, but rather quite the opposite - the experience of ignorance where we are from, what we are, and where we are going. It is only with the experience of this kind of ignorance that one can attain the bravery necessary to see the worst in oneself. The worst in people was often represented as a beast in old philosophy. Freud best learned about this beast through his research of dreams. But however much pain that beast has caused one, if encouraged by the psychotherapist's compassion, one can understand that simply because a beast exists within one does not mean that one is the same as that beast, nor that the beast will ever become a true part of one. ${ }^{47}$

In conclusion, the following fact must also not be left out. The resistance Plato saw offered by people who are unaware of themselves against philosophers like Socrates, who were prepared to encourage them to look their beasts in the face with their own eyes, accept them, and tame them, and thus heal themselves spiritually on their own (Republic 517a-b), is nearly the identical kind of resistance witnessed today by psychotherapists in the patients who come to them for help: 
"Or shall we say, here is a person (patient) who has a problem and comes to the therapist because he wants to get well? This gets closer to the real situation. But it is, unfortunately, precisely what we don't know; we cannot know that this person wants to get well. We can indeed be sure getting well is precisely what he is ambivalent about; he comes needing to remain ill until other aspects in his existence are changed. He comes in conflict and his motives are in all probability very much confused." 48

Just as the ancient philosophers who cared for mental health did not give up on believing in the human potential for mental self-healing, ${ }^{49}$ despite all resistance, modern psychotherapists are never lacking in this belief.

44

This kind of compassion should be differentiated from pity. Pity is a feeling of care towards the suffering of others. However, while pity can present itself as a neurotic symptom, honest compassion cannot. The representatives of gestalt psychotherapy have a firm opinion on this subject: "When concern for the sufferings of others is genuine and not a mask for standoffish, jubilant self-congratulation, it entails the urge to help in a practical fashion and to assume responsibility for changing the situation. In such cases we are more likely to speak of sympathy or compassion, an entering into and an active participation in the sufferer's situation. These attitudes enmesh themselves with the actuality and are too engaged in it for the luxury of sentimental tears. Tearful pity is mostly a masochistic enjoyment of the misery." See: Frederick Perls, Ralph F. Hefferline, Paul Goodman, Gestalt Therapy. Excitement and Growth in the Human Personality, Souvenir Press, London 2013, pp. 154-155.

45

F. Carl R. Rogers, On Becoming a Person. A Therapist's View of Psychotherapy, Constable, London 2004, p. 196.

46

Cf. Chris Mace, "Therapeutic questioning and Socratic dialogue", in: Chris Mace (ed.), Heart \& Soul, pp. 13-29; P. Hadot, Philosophy as a Way of Life, pp. 147-179.

47

It is interesting to note that, more than two thousand years before Freud, Plato claimed that the soul of man also encompassed the dark life of a beast, which was most visible to man in his dreams but which also raged while he was awake, although he was merely not so aware of it when awake. According to Plato, that beast was tied with the mental illness that tested man with shamelessness, under the influence of which he dared to imagine sexual relations with his own mother or any other man or anima, murder, and gluttonous excess in food and drink. According to Plato, the beast within us could only be tamed with words, through which man became aware of himself - cf. Plato, Republic 571c-572b.

48

R. May, Psychology and the Human Dilem$m a$, p. 93.
49

One of the best known recorded examples of psychotherapy in the history of philosophy is that between Descartes and Elizabeth Charlotte, Princess of the Palatinate. According to a letter Elizabeth wrote to Descartes on 7 July 1644, the philosopher was the most excellent caretaker of her soul. Descartes considered ethics the final and highest level of wisdom, and he considered ethics to be the practical psychology he outlined in Discourse de la méthode (Discourse on Method) and developed more thoroughly in Les passions de l'amé (Passions of the Soul). The princess was chronically depressive. Descartes considered a fever the princess suffered from to be an external sign of depression. Remaining consistent with what he wrote in Discours de la méthode under the third maxim of so-called provisional moral, by creating an intimate dialogue in which he expressed understanding for the princesses suffering, he compassionately encouraged the princess to discover her own power of self-healing. Descartes then states, by his own example, that everyone who seeks mental healing whatsoever in the external instead of the internal, attempting to instinctively change the order of the world and defy fate, is unable to attain mental health. In her letters, the princess thanks Descartes for his patience and advice, and frequently mentions that she is not sane enough to be sure of herself as he is. She often asks if there might not be illnesses that can completely remove oneself of their reason, and weaken one to the extent that they become prone to give into their passions against their will. Descartes, on the other hand, always patiently answered that no one lacks reason to the extent as to be unable to seek happiness only in what they are able to control. Cf. Charles Adam, Paul Tannery (ed.), Eeuvres de Descartes, I-XI, Vrin - C.N.R.S., Paris 1964-1976). Medicina animi represented the highest level of wisdom to other modern philosophers as well, such as Spinoza and Leibniz. Cf. Walther Riese, "Descartes as a Psychotherapist. The Use of Rational Philosophy in the Treatment of Discomfort and Disease", in: Medical History 10 (3/1966), pp. 237-244, doi: https://doi. org/10.1017/s0025727300011108; Herman de Dijn, "Ethics as Medicine for the Mind (5p120)", in: Michael Hampe, Ursula Renz, Robert Schnepf (ed.), Spinoza's Ethics. A Collective 


\title{
Marko Tokić
}

\section{Susret između filozofije i suvremene psihoterapije}

\section{Sažetak}

Rad nastoji razotkriti zaboravljenu perspektivu liječenja ljudske duše - jednu koja ne pripada povijesti medicine, nego povijesti filozofije, time naglašavajući vezu između filozofije i suvremene psihoterapije, pri čemu se ispituje i odnos suvremene psihoterapije i psihologije/psihijatrije. Slijedi da psihoterapija nije značajno određena znanjem bitno pripadajućem psihologiji ili psihijatriji unatoč tome što psihoterapija uključuje postupke zasnovane na znanstvenoj i teoretskoj bazi psihologije. U zaključku, dokazuje se da nije znanje, u suvremenom smislu, to koje djeluje kao determinanta za psihoterapiju, nego je to oblik suosjećanja karakterističan za filozofa.

\section{Ključne riječi}

filozofija, psihoterapija, psihologija, psihijatrija, neuroza, patnja, suosjećanje

\section{Marko Tokić}

\section{Begegnung von Philosophie und moderner Psychotherapie}

\section{Zusammenfassung}

Die Arbeit versucht, die vergessene Perspektive der Behandlung der menschlichen Seele aufzudecken - eine, die nicht der Geschichte der Medizin angehört, sondern der Geschichte der Philosophie - indem sie den Zusammenhang zwischen Philosophie und moderner Psychotherapie akzentuiert, wobei auch das Verhältnis zwischen moderner Psychotherapie und Psychologie/Psychiatrie untersucht wird. Daraus folgt, dass die Psychotherapie nicht signifikant durch das Wissen bestimmt wird, das wesenhaft zur Psychologie oder Psychiatrie gehört, obgleich die Psychotherapie Verfahren einbezieht, die auf der wissenschaftlichen und theoretischen Basis der Psychologie fußen. Schlussfolgernd wird bewiesen, dass das Wissen im modernen Sinne nicht das ist, was als Determinante für Psychotherapie fungiert, sondern es eine Form von Mitgefühl ist, das für den Philosophen kennzeichnend ist.

\section{Schlüsselwörter}

Philosophie, Psychotherapie, Psychologie, Psychiatrie, Neurose, Leiden, Mitgefühl

\section{Marko Tokić}

\section{$\underline{\text { Rencontre entre la philosophie et la psychothérapie contemporaine }}$}

\begin{abstract}
Résumé
Ce travail s'attache à révéler la perspective oubliée du soin de l'âme humaine-perspective qui n'appartient pas à l'histoire de la médecine mais à l'histoire de la philosophie, mettant ainsi l'accent sur le lien entre la philosophie et la psychothérapie contemporaine, et interrogeant par là également le rapport entre la psychothérapie contemporaine et la psychologie/psychiatrie. Il s'ensuit que la psychothérapie, même si elle inclut des procédés fondés sur une base scientifique et théorique de la psychologie, n'est pas déterminée de manière significative par une connaissance qui appartient essentiellement à la psychologie ou à la psychiatrie. En conclusion, il est démontré que ce n'est pas la connaissance, dans son sens contemporain, qui joue un rôle déterminant pour la psychothérapie, mais plutôt une forme d'empathie caractéristique pour le philosophe.
\end{abstract}

\section{Mots-clés}

philosophie, psychothérapie, psychologie, psychiatrie, névrose, souffrance, empathie

Commentary, Brill, Leiden - Boston 2011, pp. 265-281; Hubertus Busche, "Die innere Logik der Liebe in Leibnizens Elementa juris
Naturalis", Studia Leibnitiana 23 (2/1991), pp. $170-184$ 